\title{
Seasonal variability in nutritive value of ruminant diets under open grazing system in the semi-arid rangeland of Sudan (South Darfur State)
}

\author{
Awad O. Abusuwar ${ }^{1}$ and Elhadi O. Ahmed ${ }^{2}$ \\ ${ }^{1}$ Dept. of Arid land Agriculture, Faculty of Meteorology, Environment and Arid land Agric., \\ King A/Aziz University, Jeddah/Saudi Arabia \\ E-mail: abusuwar@yahoo.com \\ ${ }^{2}$ Ennhod Desert Sheep Research Station, North Kordofan State/Sudan \\ ABSTRACT
}

\begin{abstract}
A study was conducted over a two-year period (2006/07-2007/08) to evaluate the seasonal variability of ruminant diets under open grazing system in a semi-arid rangeland of Sudan( Darfur State). Measurements included dry matter production, crude protein and crude fiber of the diet for different classes of animals( cattle, sheep and goats). Results indicated that dry matter production and nutritive value in terms of crude protein and crude fiber were largely affected by seasonality and precipitation. Early dry season, which immediately follows the end of the rainy season, provided higher dry matter and nutritious forages compared to late dry season. This would suggest providing grazing animals with supplementary feed in the late grazing season for satisfactory production.
\end{abstract}

Key words: open grazing, seasonality, dry matter, nutritive value

\section{INTRODUCTION}

Ruminant livestock in most parts of the tropics graze intensively on naturally growing forages which are poor in quality. These tropical forages compared to those in the temperate pasture usually contain less nitrogen and are less digestible( Minson, 1980). The quantity and quality of these grasses became more critical in the dry season imposing more serious constraints to the development and productivity of these animals( Darrag ,1995). The severity and duration of lower quality feed differ from one country to the other within the region. Minson(1982) indicated that low protein levels characteristics of tropical forages during the long dry season are the limiting factor in animal intake and performance.

In general, the majority of the ruminants in subSaharan Africa are raised on rangelands where feed resources are mostly natural grazing grasses, forbs with some browse shrubs and trees. The husbandry systems are either nomadic, semi-nomadic or settled. Stock owners with large herds often practice full pastoralist, while those who are agro-pastoralists often have small herds and are sedentary or settled .The global grazing habit of a large number of domestic ruminants has a detrimental effect on the environment, especially as the stocking density can be very high in marginal grazing areas. The high stocking density and fewer water points in these zones, erosion due to constant trampling around water points can be added to detrimental effect of overgrazing.
The available literature on vegetation of the Sudan is essentially that of Andrews (1956) and Harrison and Jackson (1958). The classification done by Harrison and Jackson was detailed and shows an ecological approach. Ramsey did a quantitative study for determining the species composition and abundance in the Baggara country in Darfur and Kordofan. Harrison vegetation map is still being considered the only available source of information on the country grazing resources.

Under Sudan's savannah environment the pasture is composed of a predominantly annual grasses with some forbs. Skerman (1965) showed that annuals constitute $80 \%$ and perennials $20 \%$ of the forage plant composition. Annuals are the most important forage in the livestock economy of the Baggara country and all appear to be eaten.

Studies on browse and browsing impacts on woody plants in African savannahs showed that browse could be a significant part of the total food for large herbivores. Browse and shrubs can supplement the quantity and quality of pastures for grazing livestock. They are an effective insurance against seasonal feed shortages. Fodder trees and shrubs constitute vital components in livestock productivity in arid and semi-arid zones. The main feature of browse plants is their high crude protein (CP) and mineral contents. The concentration of $\mathrm{CP}$ in the leaves and fruits of the majority of fodder trees and shrubs is above $10 \%$ even in the dry season when it tend to decrease. 
Generally, Calcium and Potassium content are higher than those of other minerals (Backlund and Belskog,1991). Browsers can consume various parts of woody plants: leaves, twigs, thorns, bark, wood, bulbs, tubers, roots, flowers, seedpods and fruits (Le Houerou, 1980). He also reported that the browse refers to potential food from woody perennials, trees, shrubs and dwarf shrubs.

In the semi-arid rangeland of Sudan where this study was conducted, free grazing of rangelands is the most common feeding system for livestock production. Seasonal movement of herders from the wet grazing sites to the dry summer grazing domains is the rule for utilizing natural rangelands. Baashar(1966) stated that the Baggara tribe are not nomadic from choice, but the dry nature of their country forced them to keep on the move so as to get the best water and maximum forage for their animals.

It is quite evident that there are great variations in the chemical composition of the grasses within season's. Bremaud and Pagot (1962) studied the nutritive values of some herbaceous forage. They collected a bulk of grasses from the low rainfall woodland savannah formation in West Africa in three different seasons. During rainy season (August - September), Start of dry season (November - December) and the late dry season (April - May). They found that there is a tremendous drop in the protein contents during the dry season. This indicated that the grasses alone in their hayed state will not keep stock in anything but maintenance condition. Under such semi-arid condition, for high proportions of sheep, goats and cattle, browse is of great importance in balancing protein deficiency during the long dry summer season.

On native rangelands, a greater number of available plant species means that cattle have more feeds to choose from. Thus, in large fields cattle can adjust their diets and select plants that may be more palatable and nutritious as the grazing season progresses. Holechek, et al, (1983) noted that in open park land, pastures- as season progresses, cattle diet include a greater proportion of forbs and shrubs. Forage stands are not diverse as seeded stands but generally have a narrow season of palatability and this can create livestock nutritional problems.

Moderate grazing on natural rangelands will reduce species dominance and increase the amount of other species. Recent study undertaken by Grasslands national park staff in America, on grazed and ungrazed sites showed that cattle do not compete with native prairie ungulate species to any great extent. However, in forested pasture, cattle diets can be composed of more than $25 \%$ browse, and so livestock compete directly with native browsers .Use of browse by livestock generally increases as the dry grazing season progresses.

Harrison (1955), observed the high grazing pressure upon Zornia spp. and Blepharis linarifolia (legume herbs), by the nomadic livestock during rainy season. He related this palatability to the high protein content of both spp., especially during the wet season. According to Andrews (19656) - Blepharis linarifolia was only utilized by cattle when it is green but when, dry it is only utilized by sheep and camels.

The effect of seasonality on ruminant livestock production is also very important, in the mid season forage biomass is higher in quality and quantity, with crude protein up to $9 \%$ in most of native vegetation. Natural grasses and leguminous herbs are rich and highly digestible at this period .As the dry season set in, the protein level drops and the roughage quantity increases. There is an increase in lignin content and voluntary intake decreases. This poor feed resources, result in weight loss and decreased fertility, milk yield up to 4-5 months of the year. The severity and duration of lower quality feed differ from one country to the other within the region. Minson (1982) indicated that low protein levels characteristic of tropical forages during the long dry season are the limiting factor in animal intake and performance. To worsen the ecology and its available feed resources, further, there is widespread annual burning of native grasslands, thereby drastically reducing the amount of forage on offer. Indeed, it has been observed that a combination of these factors - low quality roughages and bush burning, which reduce the biomass available in quantity and quality - could lead to weight losses ranging from 300-400grams per head per day for cattle (Minson,1980) and up to $15 \%$ of body weight in sheep (Minson, 2982).

Dietary preference studies of indigenous animals in northern Kenya showed that cattle depends mainly on grasses and ate fewer plant species than other livestock species. Goats preferred to browse in all seasons; the sheep selected more grasses in the wet season but consumed more browse in the dry season. There is a dietary overlap - which is the potential competition between the different animal breeds for available forage - which is high between cattle and sheep during early dry season but during late dry season, competition may reach critical 
proportions if animal depend on few plant species. Different feeding behaviors and variable dietary overlap of different animal species suggest that multipurpose species grazing system might help to stop further degradation and already degraded areas.

In many arid and semi-arid areas of the world, uneven rainfall distribution leads to fluctuations in the quantity and quality of forage available to animals. In Kenya also it is observed by some researchers that forage is plentiful during and immediately after the rainy season as the case of many semi-arid rangelands in the tropics. The forage becomes scarce during the dry season, and some annual forage may disappear altogether. Different animals have evolved various mechanisms for coping with fluctuations in feed quality and availability (Minson,1980), some select high quality plants to feed on (Minson,1982), other improve the digestion of poor forage by prolonging the retention time of feed particles in the fore stomach and some adopt both mechanisms (Van Soest, 1982).

The availability of pasture in terms of quantity and nutritive value of its components reflect the characteristic of the species present, and the environment which determinates their growth and senescence (Humphreys, 1991). The quality of the harvested forage depends largely upon its protein contents and total digestible nutrients. Butter and Bialy (1973) reported that early growth stage of forage plants, the leaf contain high moisture, protein, mineral and low in fiber. The cell constituent as protein, lipids, soluble carbohydrates and soluble minerals decreased with increased age and cell fiber increased and become more lignified (Mirton et al., 1973). Quality of pasture affects fibrolytic activity of rumen micro-organisms which may be restricted when poor quality forage is fed (Fondevila et al., 1995).

Poor quality forage remains in the stomach of the animal about twice as long as does high quality one. As the level of the roughages increased in the rations, the digestibility of the energy, dry matter, organic matter and nitrogen -free extract will be decrease and the crude fiber digestibility will increase (Roy, 1979).

One of the major constraints to livestock productivity in this region is inadequacy of nutritious feed on a year-round basis, so the communal grazing is best suited during wet and dry summer seasons. Hence the objective of this study was to asses livestock diet quality during early wet and late dry summer grazing seasons.

\section{MATERIALS AND METHODS}

Study area: The study area (Eddein region) is located in the south-eastern part of South Darfur State between latitudes $9^{\circ}-30^{\prime}$ and $11^{\circ}-45$ north and longitudes $25^{\circ}-30^{\prime}$ and $27^{\circ}$ east,ecologically in the low rainfall woodland savannah with an annual rainfall between $400-600 \mathrm{~mm}$. The type of the grazing grounds depends on the vegetation that occupies the leveled sand, cracking and non-cracking clay soils.

Vegetation types and distribution are closely associated with rainfall, as the amount of rainfall increases from north to south, so do respective types, heights and diversity of the over story and under story vegetation (El-Hag et al, 1984).

The following shrubs and trees species are found on the sandy soils in the northern part of Dar- Rezaigat communal land: Ziziphus spina christi, Combretum cordfanum, Acacia senegal, Guiera senegalensis, Boscia senegalensis, and Calotrpis procera. The herbaceous vegetation include: Cenchrus spp., Zornia spp., Eragrostis spp., Aristida spp. and Brachiaria spp.

On the Baggara Repeating Pattern, the dominant over storey vegetation include: Grewia tenax, Acacia mellifera, Acacia nubica, Anogeisus schimperi, Combretum spp., and the herbaceous cover include Sporobolus festivus, Sporobolus marginata, Aristida funiculata, Dactloctenium aegyptiaca, and Brachiaria spp. On the Ragaba Repeating Pattern of its different clay soils (Gardud, Talha, and Fawa), the dominant overstorey vegetation include: Acacia seyal, Acacia gerrardii, Acacia nilotica, Acacia seiberana, and the herbaceous strata in these different soil types include: Hygrophylla spinosa, Hyparrhenia rufa, setaria incrasata, Echinochloa stagnina, Digitaria spp. and Tephrosia spp. Concerning the kinds of the herbaceous forage plants and browse overstorey vegetation that is selected by the livestock in the Baggara Country as reported by Elzubeir, (1984) include: Brachiaria spp., Digitaria spp. and Setaria spp. among the platable herbaceous plants. Tetrapogon cenchriformis and Echinochloa colonum are also palatable but, its occurrence is limited to the edges of water-holding sites. Among the dominant perennial herbs are: Euophorbia spp., Pavonia patens, Chrozophora brocchiana and Aerva javanica. There is some perennial grasses preferred much by livestock include Sporobolus festivus ,Aristida stipoides, Aristida ciliata, Schoenefeldia uniflora, and Oryza breviligulata, and the most important herb 
legumes which stand somewhat heavier grazing are Stylosanthes fraticosa and Tephrosia bracteolate.

The most browse vegetation are Bauhinia rufescena, Cadaba farinosa Digitaria spp.,Setaria spp., both species are ever-green - in addition to these browse Acacia mellifera ,Boscia senegalenses, Grewia tenax , Albizia amara , Combretum spp. especially Combretum acculatum ,Dalbergia melanozylon ,Geuera senegalensis Balanites aegyptiaca, Maerua crassifolia are all browsed by livestock when they are young. These species provide the bulk of stock grazing during the wet and dry seasons.

Field study: The study was conducted in the Baggara country of the Rezaigat communal land. The total area of the study region is about 60,000 sq. $\mathrm{km}$. It is one of the most important cattle raising regions in the Sudan, and it shows the exact location of the Baggara Country that extends from Kordofan to Darfur in the low rainfall woodland savannah ecological zone.

Methodology: The diets selected by the free-ranging animals (cattle, goats and sheep) were determined from the bite-count method (Van Dyne ,1968). The bite-count method involves the selection of an animal from the surrounding grazing herds at each site. Each animal was followed for 10 minutes in the morning and in the evening for two consecutive days. About 100 bites were recorded each day. The bite of each animal represents the kind and the number of plants chewed by the specified animal. Plant materials representative to that selected by each animal breed were clipped, sun-dried and then oven -dried at $40^{\circ} \mathrm{C}$ until a constant weight was reached, then samples were ground to carry proximate analysis. Sampling of livestock diets have been obtained once during the grazing of the nomadic herds in the wet and dry grazing locations.

Samples from these animal diets were chemically analyzed by using the proximate analysis according to AOAC (1984) method. In this study the Dry matter, Crude protein and the Crude fiber were assessed.

\section{RESULTS AND DISCUSSION}

Among other factors, vegetation type in rangelands is largely determined by rainfall. Rainfall as determined by isohyets for the Sudan is presented in Fig. 1 and the vegetation types are shown in Fig.2. The study area lies between isohyets 300 and $400 \mathrm{~mm}$ of rainfall as indicated by the small square in the western part of the country (Fig.1)which coincided with low rainfall woodland savannah in the vegetation map (Fig.2).

As indicated in Table 1, the percent dry matter and crude fiber for different classes of animals were higher during year 2 (season 2007/08) compared to year 1 (season 2006/07). Rainfall data recorded for the study area indicated that total rainfall during year 2 was $825.1 \mathrm{~mm}$ compared to $430.4 \mathrm{~mm}$ during year 1. Therefore, it was expected to have higher dry matter in year 2 since precipitation was two-folds of that in year1. This was also reflected in the percent crude protein especially for goats. Goats are known to be selective grazers picking twigs and young leaves of shrubs and trees which are higher in crude protein. Cattle and sheep graze only the available pastures and do not browse like goats.

As for the effect of season on dry matter, crude protein and crude fiber, the late dry season was significantly higher in dry matter compared to early dry season.

With respect to nutritive values in terms of crude protein and crude fiber, the early dry season had a higher crude protein percent than late dry summer. This is because early dry summer immediately follows the end of the rainy season, therefore the vegetation was still nutritious compared to late season. Results of crude protein percent in this study matched those reported by Minson (1980) who indicated that crude protein contents of most pastures in the low rainfall woodland savannah are higher only during the rainy season and decreases as the dry season advances.

No significant differences for crude fiber percent as affected by season although they were higher during the early season. The lower crude fiber percent reported for in goats diet strongly confirmed the high digestible feed selected by goats compared to sheep and cattle. Mckel (1980) indicated that in tropical pastures the crude fiber usually ranges between 30 to $40 \%$ of the dry matter in mature plants. 
Agric. Biol. J. N. Am., 2010, 1(3): 243-249

Table 1. The nutritive value of animal diets (as \%of dry matter) for cattle, sheep and goats as affected by class of animal and season

\begin{tabular}{|c|c|c|c|c|c|c|c|}
\hline Factors & Periods & \multicolumn{2}{|c|}{ Dry matter \% } & \multicolumn{2}{|c|}{ Crude fiber \% } & \multicolumn{2}{|c|}{ Crude protein \% } \\
\hline Animal class & Years & Early & Late & Early & Late & Early & Late \\
\hline \multirow{2}{*}{ Cattle } & First year & 94.70 & 94.97 & 39.33 & 39.83 & 5.03 & 3.23 \\
\hline & Second year & 95.47 & 95.80 & 45.00 & 42.33 & 3.89 & 4.56 \\
\hline \multirow{2}{*}{ Sheep } & First year & 94.83 & 95.37 & 38.67 & 42.67 & 5.34 & 4.22 \\
\hline & Second year & 95.33 & 95.80 & 44.33 & 39.00 & 4.31 & 6.16 \\
\hline \multirow{2}{*}{ Goats } & First year & 94.13 & 94.03 & 36.17 & 31.67 & 8.75 & 6.84 \\
\hline & Second year & 95.33 & 94.40 & 40.33 & 37.00 & 5.35 & 6.28 \\
\hline \multicolumn{8}{|l|}{ Main effects } \\
\hline \multirow{3}{*}{ Season } & Early dry season & \multicolumn{2}{|c|}{$94.47 \pm 0.54 b$} & \multicolumn{2}{|c|}{$40.64 \pm 3.94$} & \multicolumn{2}{|c|}{$5.44 \pm 1.98$} \\
\hline & Late dry season & \multicolumn{2}{|c|}{$95.23 \pm 0.70 a$} & \multicolumn{2}{|c|}{$38.75 \pm 4.86$} & \multicolumn{2}{|c|}{$2.22 \pm 1.75$} \\
\hline & Significance & \multicolumn{2}{|c|}{$0.05^{\star \star-x}$} & \multicolumn{2}{|c|}{$0.09 \mathrm{NS}$} & \multicolumn{2}{|c|}{$0.01^{* \ldots k \ldots}$} \\
\hline
\end{tabular}

Means within the same column followed by different superscriptions are significantly different

*** highly significant at $(P<0.01)$

** significant at $(P<0.05)$

NS: not significant

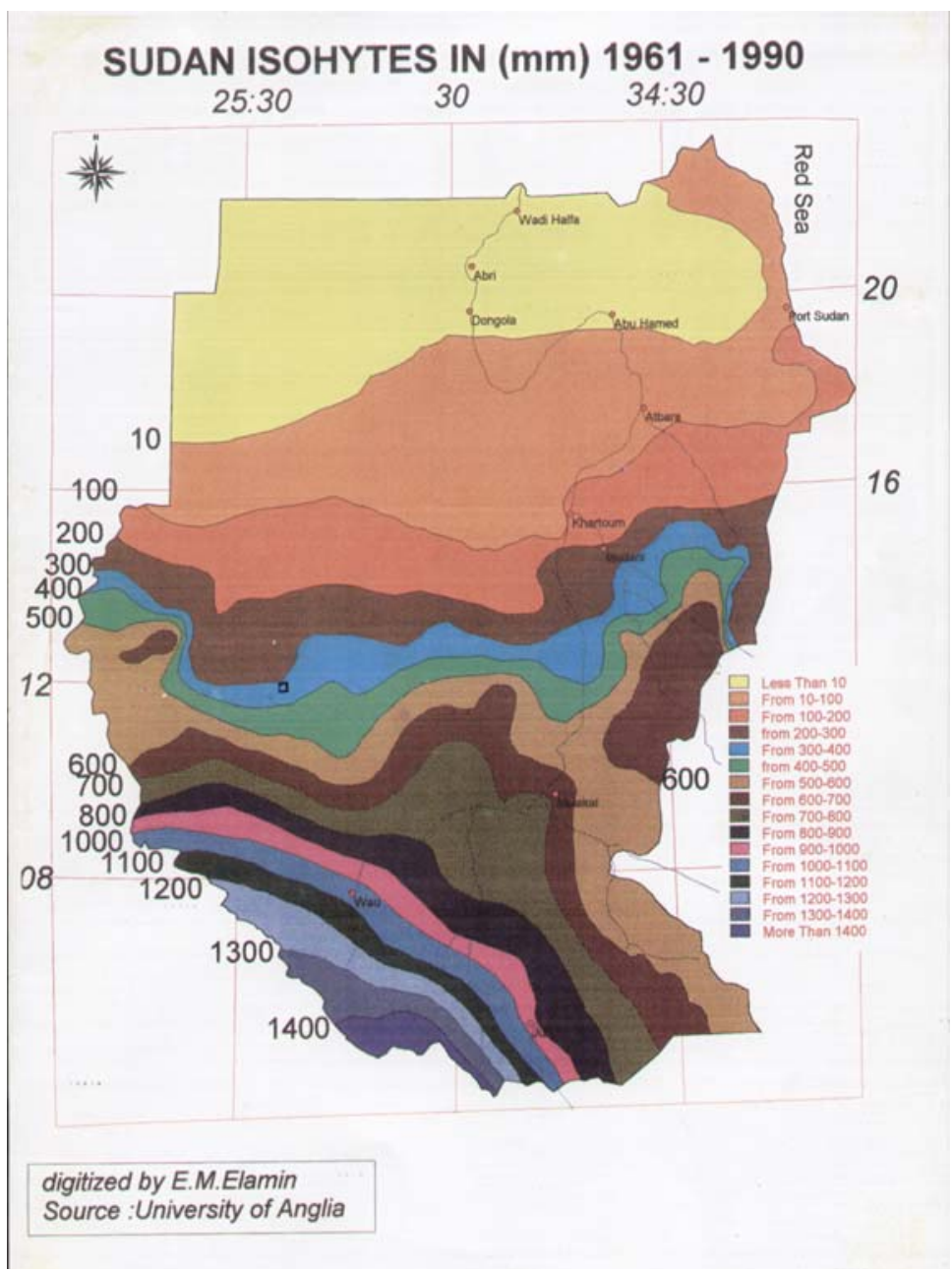

Fig. 1. Sudan Isohyets in (mm) 1961-1990 
Agric. Biol. J. N. Am., 2010, 1(3): 243-249

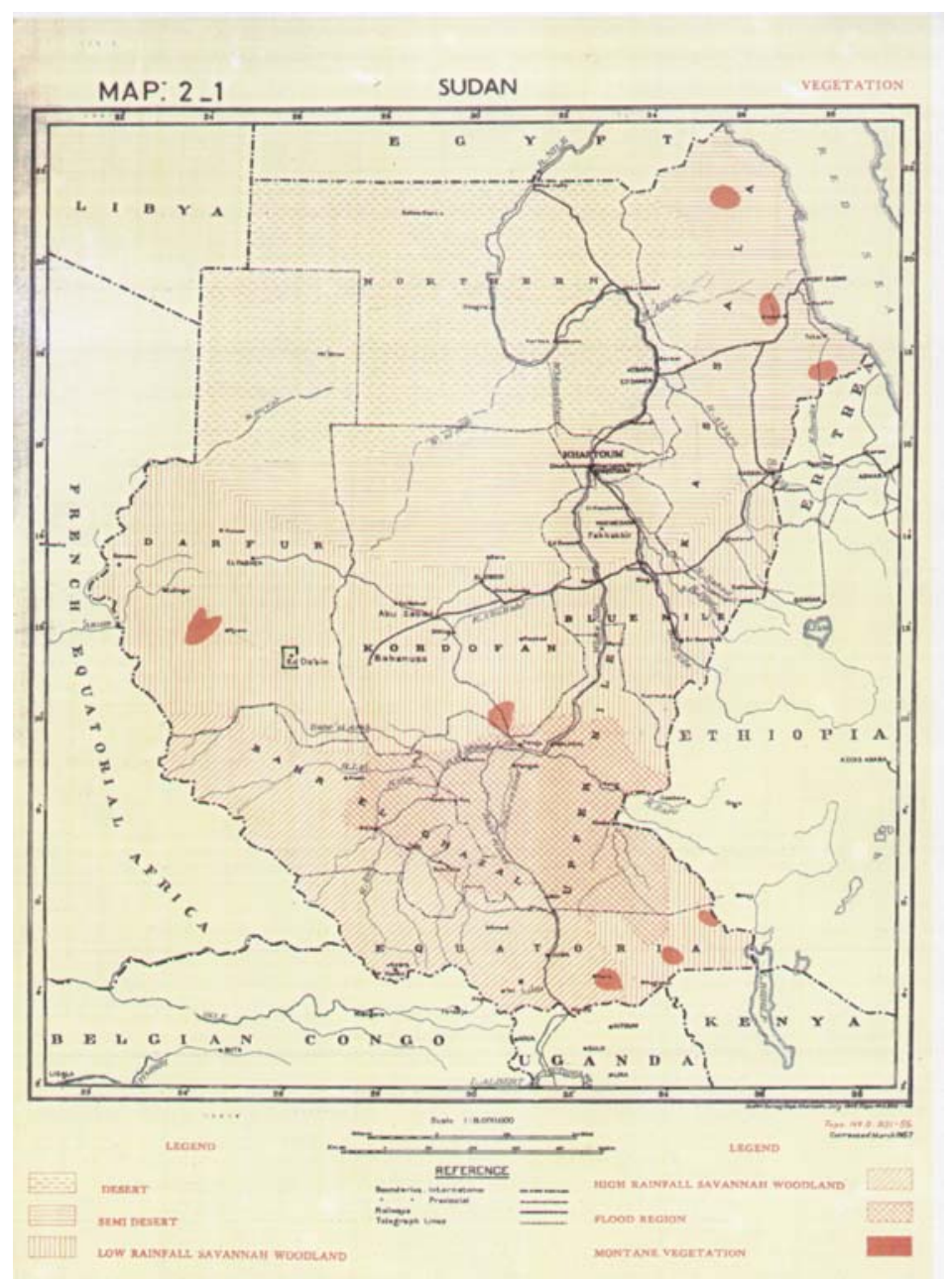

\section{CONCLUSION}

It can be concluded from the results of this study that dry matter content of natural rangelands in the low rainfall woodland savannah is largely determined by precipitation. The presence of different classes of livestock in the same herd would be beneficial as they differ in their grazing habits and therefore their grazing preferences differ which will benefit the vegetation as the grazing pressure will be distributed among different types of plants. The nutritive values of the forage drops as the dry season advances which might suggest provision of feed supplements late in the dry season.

\section{REFERENCES}

A.O.A.C. (1984). Official methods of the analysis of the Association of Official Analysis, Chem. $14^{\text {th }}$ ed. Published by the A.O.A.C Inc. North Nineteenth Street, Suite 210 Arlington. Virginia, 22209-USA.

\section{An}

Andrews, F.W. (1956). The flowering plants of the AngloEgyptian Sudan Volume (3), Buncle. Co. Ltd. Arbroth, Scotland.

Baashar ,M.M.(1966) . Livestock development in the central rangelands of the Sudan -potentials and problems .Proc. $13^{\text {th }}$ Annual conference, phill, society ,Sudan,(2) ,pp.276-397

Backlund, M. and Belskog,J,(1991) . The role of trees and shrubs in livestock production in central Tanzania .A survey of their nutritive value during the dry season Swedish University of Agricultural Science International Development Centre, Uppsala 24 p.

Bremaud and Pagot (1962). Percentage change in seasonal nutrient values of some herbs in the Sahel of Sudan.

Butler, G.W., and Bialy, R W. (1973). Range of protein in the leaf cells Chemistry and biochemistry of herbage, Vol. (1), pp. 67. 
Darrag, A. (1995). Range and feeding balance in livestock.paper presented in the workshop on pastoralism and pasture resource development sector in Kosti (in Arabic).

El-Hag, F.M., Ahmed, M.M.M., Fadlalla, B., El-Amin, E.M., El-Wakeel A.S. and Mekki, M.A. (2003). Seasonal performance of Zebu Cattle under two production systems in South Kordofan State, published by Agricultural Research Corporation,Wadmadani,Sudan.

Fondevila, M., Castrillo, C., Gassa, J. and Guada, J.A(1995). Rumen undegradable dry matter and neutral detergent fiber as ratio indicator in sheep given cereal straw - based diets, Journal of Agricultural science (125), 145-151.

Harrison, M.N. (1955). A report on grazing survey for the Sudan. Khartoum mimeographed- and better known as (Harrison report).

Harrison, M.N. and Jackson, J.K. (1958). Ecological classification of the vegetation of the Sudan. Forest Bulltein No. (2), (New series). Publication committee, Khartoum, Sudan.

Humrphey, L.R.(1991).Tropical pasture utilization, Cambridge University Press, London

Holechek, J.I., M. Vavra and R. Pieper (1983). Methods for determining the botanical composition, similarity and overlap of range herbivore diets, In: G.M.VAN Dyne, J. Brotnov, B.Burch and S. Fairfax and B. Huey, eds. National Research Council.

Le Houerou, H.N. (1980). Role of browse in the Sahelian and Sudanian Zones, In: Browse in Africa, The current state of knowledge, H. N. Le Houero (ed), ILCA, Addis Ababa, Ethiopia.

McDonald, P., Edwards, Greenhalgh, J.F.D and Morgan, C.A, (2002). Animal Nutrition, $6^{\mathrm{th}}$ edition, Prentice Hall, London, England pp. 693.

McKell, C.M. (1980). Multiple uses of fodder trees and shrubs, a world-wide Perspective. In: Le Houerou, H.N. (editor), Browse in Africa Current state of knowledge. ILCA, Addis Ababa, Ethiopia pp.141-150.

Mnison, D.J. (1980). Nutritional differences between tropical and temperate pasture. In: Morley, F.H.N. (Editor). Grazing animals. Elsevier, Amsterdam, Netherlands. 103-157.

Minson, D.J. (1982). In: Grazing animals. Pp. 143-158 In: Morley, F.H.N (Editor). Grazing animals. Elsevier, Amsterdam, Netherlands.

Roy, A. Chessmore (1979). Profitable pasture management. The Interstate Printers and Publishers, New York, pp. 230Meirion, Thomas, Ranson, S.L., and Richardson, J.A. (1973). The rate of increase in dry matter. Plant physiology $5^{\text {th }}$. Ed. pp.273.

Skerman, P.J. (1965). Ecological Observation of studies in Kordofan Special Fund Project, FAO (1962-1965).

Van Dyne, G.M. (1968). Measuring quantity and quality of the diets of large herbivores. In: Practical Guide to study of the productivity of large herbivores F.B. Galley and H.K. Bukgner, eds. Blackwell Scientific Publication, Oxford, England.

Van Soest, P.J. (1982). Nutritional Ecology of ruminant. O and B Books, Inc., Corvallis, Oregon, USA. 